\title{
EFFECTS OF FOLIAR APPLICATIONS OF SOME MACRO AND MICRO NUTRIENTS ON YIELD, QUALITY ATTRIBUTES OF GUAVA (PSIDIUM GUAJAVA L.)
}

\author{
Hemant Saini, Rajender Kumar Godara, Poonam Saini*, ViJay \\ AND SOURABH
}

Department of Horticulture, CCS Haryana Agricultural University, Hisar, India

Keywords: Macronutrients, Micronutrients, Foliar application, C: N ratio, NPK

\begin{abstract}
Effects of foliar applied macro (NPK) and micro nutrients (Fe, Mn, $\mathrm{Zn}, \mathrm{Cu}$ and $\mathrm{B}$ ) at different time on yield, quality and benefit: cost ratio of rainy and winter season guava were evaluated in north western Haryana, India. The two season's data depicted that physico- chemical characters with respect to fruit set, fruit retention, fruit size, average fruit weight and yield were significantly increased with foliar application of macro and micro nutrients at vegetative, flowering and fruiting stage $\left(\mathrm{T}_{7}\right)$. The shoot $\mathrm{C}$ : $\mathrm{N}$ ratio was also found highest with $\mathrm{T}_{7}$ foliar treatment which was followed by $\mathrm{T}_{5}$ in both the seasons. The $\mathrm{T}_{7}$ foliar spray resulted in maximum benefit: cost ratio in both the seasons. Proper fertilization strategies can help fruit growers to get good yield and quality fruits.
\end{abstract}

\section{Introduction}

Guava (Psidium guajava L.) being a tropical fruit also grows well in sub-tropical conditions (Bal 2006) due its wider adaptability in diverse soils and agro climatic regions. It is popularly known as Poor man's apple because of low cultivation cost. India, Brazil and Mexico are main producers of guava in the world. This evergreen tree occupies an area of 2.62 lakh hectare with annual production of 36.48 metric tonnes and annual productivity of 13.92 metric tonnes per hectare in India. Uttar Pradesh leads in area and production while, Haryana ranks tenth (Saxena and Gandhi 2017). The immense nutritive values along with sturdy nature and prolific bearing habit even on marginal land have made guava farmer's first choice.

The excess use of chemical fertilizers has posed environmental threat, soil nutrients imbalance and deteriorated the micronutrients and organic carbon content in soil (Kharwade et al. 2018). Therefore, to tackle this problem judicious supply of macro as well as micro nutrients is required. Right selection of fertilizer dose, time of application and method of application can positively influence the fruit yield and quality, fetching good price in the market. The effectiveness of fertilizers increases 10 to 20 times when applied through foliage (Zaman and Schumann 2006) because of low application rates, uniform distribution of nutrients and quick absorption by the leaves. Therefore, the present study was aimed to standardize an economic fertilization strategy that can give farmers a good yield of quality guava.

\section{Materials and Methods}

The present field study was carried out in experimental orchard of Department of Horticulture, CCS Haryana Agricultural University, Hisar, Haryana, India. The 18 year old Hisar Safeda guava trees were sprayed with eight treatments viz., $\mathrm{T}_{1}=\mathrm{RDF}+$ Foliar spray of NPK (19:19:19) at $2 \%$ and micronutrients Fe (1300 ppm), Mn (1600 ppm), Zn (1600 ppm), Cu (1000 ppm) and B (1000 $\mathrm{ppm})$ at vegetative stage (April and October), $\mathrm{T}_{2}=\mathrm{RDF}+$ Foliar spray of NPK (12: $\left.32: 16\right)$ at $2 \%$

\footnotetext{
*Author for correspondence: <punamsaini5294@gmail.com>.
} 
and $\mathrm{Fe}(500 \mathrm{ppm}), \mathrm{Mn}(800 \mathrm{ppm}), \mathrm{Zn}(800 \mathrm{ppm}), \mathrm{Cu}(1000 \mathrm{ppm})$ and $\mathrm{B}(2000 \mathrm{ppm})$ at flowering stage (May and November), $\mathrm{T}_{3}=\mathrm{RDF}+$ Foliar spray of NPK (16:8:34) at $2 \%$ and Fe (1200 ppm), Mn (1600 ppm), Zn (1600 ppm), Cu (1000 ppm) and B (1000 ppm) at fruiting stage (July and February), $T_{4}=T_{1}+T_{2}, T_{5}=T_{2}+T_{3}, T_{6}=T_{1}+T_{3}, T_{7}=T_{1}+T_{2}+T_{3}$ and $T_{8}=$ Control (RDF). The treatments were replicated thrice with three plants in each replication and executed in randomized block design. The per cent fruit set was calculated by formula given below:

$$
\text { Fruit set }(\%)=\frac{\text { Number of fruits set }}{\text { Total flowers counted }} \times 100
$$

The per cent fruit retention was estimated on the basis of initial number of fruit set. Fruit length and breadth of ten randomly selected fruits per tree were measured with the help of digital Vernier's Callipers and the average value was calculated and expressed in centimeter $(\mathrm{cm})$. The average weight was calculated by dividing the total fruit weight by a total number of fruits taken (10) and expressed in grams (g). The total fruit yield per tree was calculated by multiplying a total number of fruits per tree with average fruit weight and expressed in $\mathrm{kg}$ per tree. The carbohydrate: nitrogen ratio in guava shoot was calculated by dividing the total carbohydrate content by the total nitrogen content of shoot. Micro-kjeldahl method (Jackson 1973) was used for the estimation of total nitrogen content in the shoot sample and procedure of Somogyi (1952) was followed for the estimation of total carbohydrate content. The benefit: cost ratio was estimated by dividing the gross income by total input cost. The analysis and interpretation of experimental results were done by the statistical method described by Panse and Sukhatme (1985).

\section{Result and Discussion}

The per cent fruit set and retention were significantly enhanced by different foliar application of macro and micro nutrients in both the seasons (Table 1). Irrespective of seasons, highest fruit setting and fruit retention were recorded in the guava trees sprayed with $T_{7}$ treatment which was statistically at par with $\mathrm{T}_{5}, \mathrm{~T}_{6}$ and $\mathrm{T}_{3}$. The lowest fruit setting and fruit retention percentage were obtained in the trees treated with RDF $\left(T_{8}\right)$ which was closely followed by $T_{1}, T_{2}$ and $T_{4}$. The presence of zinc in the treatment combination might be the reason for higher fruit retention and fruit set as it increases the synthesis of Indole Acetic Acid (IAA) which consequently improves the endogenous level of auxin at abscission zone to avoid fruit drop. The macro and micro nutrients are important constituents of nucleotides, protein, chlorophyll and enzymes which take part in various metabolic processes and have direct impact on vegetative phases of fruit (Sharma et al. 2013). The nitrogen nutrition might promote vegetative growth at the cost of onset of reproductive phase (Verma and Chauhan 2013). The increased fruit set and retention in guava trees as a result of foliar spray of boron might be attributed to the fact that boron helps in pollen grain germination and pollen tube development in fruit crops (Ganie et al. 2013). The increased fruit set by foliar application of nutrients might be due to profuse flowering resulted from improved pollen germination and proper growth of pollen tubes which facilitated the timely fertilization, before stigma became non-functional (Jat and Kacha 2014). The maximum fruit setting and retention was observed in winter season, while minimum in rainy season. The fruit set and retention was found higher in winter season as compared to rainy season because the nutrients sprayed during rainy season might have cumulative effect later on. The lower fruit set and retention percentage in rainy season might be due to humid and high temperature which affected the overall plant ecosystem that further affected photosynthates partitioning. Moreover, insect- pest infestation might have diverted the plant's energy primarily in defense mechanism. 
Table 1. Effects of foliar application of macro and micro nutrients on per cent fruit set and retention of guava cv. Hisar Safeda.

\begin{tabular}{ccccccc}
\hline \multirow{2}{*}{ Treatments } & \multicolumn{3}{c}{ Fruit set $(\%)$} & \multicolumn{3}{c}{ Fruit retention $(\%)$} \\
\cline { 2 - 6 } & Rainy $\left(\mathrm{S}_{1}\right)$ & Winter $\left(\mathrm{S}_{2}\right)$ & Mean & Rainy $\left(\mathrm{S}_{1}\right)$ & Winter $\left(\mathrm{S}_{2}\right)$ & Mean \\
\hline $\mathrm{T}_{1}$ & 44.96 & 56.02 & 50.49 & 46.75 & 56.34 & 51.55 \\
$\mathrm{~T}_{2}$ & 45.24 & 58.09 & 51.67 & 47.96 & 57.90 & 52.93 \\
$\mathrm{~T}_{3}$ & 47.48 & 59.38 & 53.43 & 50.02 & 59.78 & 54.89 \\
$\mathrm{~T}_{4}$ & 46.89 & 58.97 & 52.93 & 48.26 & 58.21 & 53.23 \\
$\mathrm{~T}_{5}$ & 49.23 & 61.41 & 55.32 & 52.58 & 60.24 & 56.41 \\
$\mathrm{~T}_{6}$ & 49.00 & 60.23 & 54.62 & 51.16 & 59.94 & 55.55 \\
$\mathrm{~T}_{7}$ & 50.66 & 63.00 & 56.83 & 54.00 & 61.67 & 57.84 \\
$\mathrm{~T}_{8}$ & 44.13 & 55.17 & 49.65 & 44.74 & 55.48 & 50.11 \\
Mean & 47.19 & 59.03 & & 49.43 & 58.69 & \\
\hline $\mathrm{CD}$ at $5 \%$ & $\mathrm{~T}=3.75, \mathrm{~S}=2.04, \mathrm{TxS}=\mathrm{NS}$ & $\mathrm{T}=4.15, \mathrm{~S}=2.07, \mathrm{TxS}=\mathrm{NS}$ \\
$\mathrm{SEM} \pm$ & $\mathrm{T}=1.30, \mathrm{~S}=0.70, \mathrm{TxS}=1.99$ & $\mathrm{~T}=1.44, \mathrm{~S}=0.72, \mathrm{TxS}=2.02$ \\
\hline
\end{tabular}

$\mathrm{T}_{1}: \mathrm{RDF}+$ Foliar spray of NPK (19:19:19) at $2 \%$ and micronutrients Fe (1300 ppm), Mn (1600 ppm), Zn (1600 ppm), Cu $(1000 \mathrm{ppm}), \mathrm{B}(1000 \mathrm{ppm})$ at vegetative stage (April and October).

$\mathrm{T}_{2}: \mathrm{RDF}+$ Foliar spray of NPK (12:32:16) at $2 \%$ and micronutrients Fe (500 ppm), Mn (800 ppm), Zn (800 ppm), Cu (1000 ppm), B (2000 ppm) at flowering stage (May and November).

$\mathrm{T}_{3}$ : RDF + Foliar spray of NPK (16:8:34) at $2 \%$ and micronutrients Fe (1200 ppm), Mn (1600 ppm), Zn (1600 ppm), Cu $(1000 \mathrm{ppm}), \mathrm{B}(1000 \mathrm{ppm})$ at fruiting stage (July and February).

$\mathrm{T}_{4}: \mathrm{T}_{1}+\mathrm{T}_{2}, \mathrm{~T}_{5}: \mathrm{T}_{2}+\mathrm{T}_{3}, \mathrm{~T}_{6}: \mathrm{T}_{1}+\mathrm{T}_{3}, \mathrm{~T}_{7}: \mathrm{T}_{1}+\mathrm{T}_{2}+\mathrm{T}_{3}, \mathrm{~T}_{8}:$ Control (RDF).

Effects of different nutrients sprayed at different time was found significant in enhancing the fruit length and breadth, irrespective of seasons (Table 2). The maximum length and breadth were obtained in the fruits harvested from trees sprayed with $T_{7}$, which was found to be at par with $T_{5}$ and $\mathrm{T}_{6}$. The minimum length and breadth were recorded in the fruits harvested from control trees. The increase in fruit weight and size of 'Hisar Safeda' guava might be explained with the role of zinc in the synthesis of tryptophan, a precursor for indole acetic acid synthesis, which is involved

Table 2. Effects of foliar application of macro and micro nutrients on fruit length $(\mathrm{cm})$ and breadth (cm) of guava cv. Hisar Safeda.

\begin{tabular}{ccccccc}
\hline \multirow{2}{*}{ Treatments } & \multicolumn{3}{c}{ Fruit length $(\mathrm{cm})$} & \multicolumn{3}{c}{ Fruit breadth $(\mathrm{cm})$} \\
\cline { 2 - 6 } & Rainy $\left(\mathrm{S}_{1}\right)$ & Winter $\left(\mathrm{S}_{2}\right)$ & Mean & Rainy $\left(\mathrm{S}_{1}\right)$ & Winter $\left(\mathrm{S}_{2}\right)$ & Mean \\
\hline $\mathrm{T}_{1}$ & 4.14 & 4.40 & 4.27 & 4.00 & 4.28 & 4.14 \\
$\mathrm{~T}_{2}$ & 4.25 & 4.37 & 4.31 & 4.12 & 4.24 & 4.18 \\
$\mathrm{~T}_{3}$ & 4.39 & 4.74 & 4.57 & 4.24 & 4.55 & 4.40 \\
$\mathrm{~T}_{4}$ & 4.30 & 4.50 & 4.40 & 4.09 & 4.37 & 4.23 \\
$\mathrm{~T}_{5}$ & 4.69 & 5.15 & 4.92 & 4.50 & 4.98 & 4.74 \\
$\mathrm{~T}_{6}$ & 4.58 & 5.00 & 4.79 & 4.46 & 4.89 & 4.68 \\
$\mathrm{~T}_{7}$ & 4.80 & 5.20 & 5.00 & 4.76 & 5.08 & 4.92 \\
$\mathrm{~T}_{8}$ & 4.11 & 4.39 & 4.25 & 3.90 & 4.30 & 4.10 \\
Mean & 4.41 & 4.72 & & 4.26 & 4.59 & \\
\hline CD at 5\% & $\mathrm{T}=0.35, \mathrm{~S}=0.18, \mathrm{TxS}=\mathrm{NS}$ & $\mathrm{T}=0.31, \mathrm{~S}=0.17, \mathrm{TxS}=\mathrm{NS}$ \\
$\mathrm{SEM} \pm$ & $\mathrm{T}=0.12, \mathrm{~S}=0.06, \mathrm{TxS}=0.17$ & $\mathrm{~T}=0.11, \mathrm{~S}=0.06, \mathrm{TxS}=0.17$ \\
\hline Abbrevicinyyyyy
\end{tabular}

Abbreviations are similar to Table 1. 
in the growth and development of the fruit. The possible reason for the increase in size of guava fruit might be due to foliar feeding of nutrients and consequently rapid fruit development caused by easy availability of nutrients to the plants (Singh and Vashishtha 1997). The increase in fruit size and weight of guava might be due to increased cell division and expansion by boron application (Kumar et al. 2015). The maximum length and breadth were found in the fruits harvested in winter season as compared to rainy season fruits. The maximum length and breadth were observed in the fruits harvested from trees sprayed with $\mathrm{T}_{7}$ treatment during winter season. The interaction effect of different foliar sprays and seasons was found non significant with fruit length and fruit breadth.

Different foliar sprays were found to be significant with respect to average fruit weight and yield (Table 3). The maximum average fruit weight and yield were obtained from the trees sprayed with $T_{7}$ treatment which was statistically at par with $T_{5}$ and $T_{6}$, while the minimum was recorded in control trees. Iron has important function in enzymatic systems and chlorophyll formation and consequently increased photosynthesis which finally increased the yield. In addition manganese is a minor constituent of plant chlorophyll which is responsible for photosynthesis. Higazi et al. (1984) also reported that guava trees treated with NPK + micronutrients each 1500 or $3000 \mathrm{ppm}$ improved

Table 3. Effects of foliar application of macro and micro nutrients on average fruit weight and yield of guava cv. Hisar Safeda.

\begin{tabular}{ccccccc}
\hline \multirow{2}{*}{ Treatments } & \multicolumn{3}{c}{ Average fruit weight $(\mathrm{g})$} & \multicolumn{3}{c}{ Yield $(\mathrm{kg} /$ tree $)$} \\
\cline { 2 - 6 } & Rainy $\left(\mathrm{S}_{1}\right)$ & Winter $\left(\mathrm{S}_{2}\right)$ & Mean & Rainy $\left(\mathrm{S}_{1}\right)$ & Winter $\left(\mathrm{S}_{2}\right)$ & Mean \\
\hline $\mathrm{T}_{1}$ & 110.95 & 128.95 & 119.95 & 44.08 & 54.80 & 49.44 \\
$\mathrm{~T}_{2}$ & 112.78 & 130.88 & 121.83 & 45.27 & 55.68 & 50.47 \\
$\mathrm{~T}_{3}$ & 118.17 & 139.27 & 128.72 & 48.02 & 60.26 & 54.14 \\
$\mathrm{~T}_{4}$ & 115.78 & 134.32 & 125.05 & 46.52 & 57.14 & 51.83 \\
$\mathrm{~T}_{5}$ & 121.78 & 141.69 & 131.74 & 49.82 & 63.83 & 56.83 \\
$\mathrm{~T}_{6}$ & 120.60 & 139.99 & 130.30 & 49.17 & 61.97 & 55.57 \\
$\mathrm{~T}_{7}$ & 124.77 & 145.75 & 135.26 & 51.63 & 65.72 & 58.68 \\
$\mathrm{~T}_{8}$ & 109.10 & 124.00 & 116.55 & 43.04 & 52.34 & 47.69 \\
Mean & 116.74 & 135.61 & \multicolumn{5}{c}{$\mathrm{T}=4.27, \mathrm{~S}=2.14, \mathrm{TxS}=\mathrm{NS}$} \\
\hline $\mathrm{CD}$ at 5\% & $\mathrm{T}=8.11, \mathrm{~S}=5.05, \mathrm{TxS}=\mathrm{NS}$ & \multicolumn{3}{c}{$\mathrm{T}=1.47, \mathrm{~S}=0.74, \mathrm{TxS}=2.08$} \\
$\mathrm{SEM} \pm$ & $\mathrm{T}=2.82, \mathrm{~S}=1.74, \mathrm{TxS}=4.93$ &
\end{tabular}

Abbreviations are similar to Table 1.

fruit physical and chemical properties. The increase in fruit weight might be due to rapid expansion in size of cells and more accumulation of sugars in sprayed fruits (Singh and Vashishtha 1997). The increase in fruit weight by various macro and micro nutrients were recorded by Sharma et al. (1991) in guava. The increase in fruit weight might be due to the fast mobilization of metabolites into fruits and involvement in cell division and cell expansion as well as increased volume of intercellular space in mesocarpic cells (Brahmachari et al. 1997). Potassium application at higher rate might have improved the translocation of photosynthates from source to sink and ultimately yield (Verma and Chauhan 2013). The yield increased because increase in fruit set and retention on the tree consequently reduced the pre-harvest fruit drop. The winter season average fruit weight and yield were more in comparison to rainy season irrespective of different foliar sprays. The yield was not affected significantly by the interaction of different foliar sprays and seasons. The average fruit weight and yield were significantly higher in winter season because the nutrients had cumulative effect. Moreover, in winter season heavier and larger fruits were harvested due to 
congenial temperature which ultimately increased the yield as evident from the present study. Also, the increased fruit set and fruit retention percentage during winter season resulted in increased yield.

Table 4. Effects of foliar application of macro and micro nutrients on shoot C: $\mathbf{N}$ ratio of guava tree cv. Hisar Safeda.

\begin{tabular}{cccc}
\hline Treatment & Rainy $\left(\mathrm{S}_{1}\right)$ & Winter $\left(\mathrm{S}_{2}\right)$ & Mean \\
\hline $\mathrm{T}_{1}$ & 11.56 & 11.79 & 11.58 \\
$\mathrm{~T}_{2}$ & 11.40 & 12.00 & 11.70 \\
$\mathrm{~T}_{3}$ & 12.61 & 12.88 & 12.75 \\
$\mathrm{~T}_{4}$ & 12.37 & 12.84 & 12.60 \\
$\mathrm{~T}_{5}$ & 12.89 & 13.07 & 12.98 \\
$\mathrm{~T}_{6}$ & 12.47 & 12.60 & 12.54 \\
$\mathrm{~T}_{7}$ & 13.02 & 13.44 & 13.23 \\
$\mathrm{~T}_{8}$ & 10.84 & 11.59 & 11.31 \\
Mean & 12.15 & 12.53 & \\
\hline $\mathrm{CD}$ at 5\% & \multicolumn{3}{c}{$\mathrm{T}=0.94, \mathrm{~S}=\mathrm{NS}, \mathrm{TxS}=\mathrm{NS}$} \\
$\mathrm{SEM} \pm$ & $\mathrm{T}=0.32, \mathrm{~S}=0.16, \mathrm{TxS}=0.46$ \\
\hline $\mathrm{Abbr}$
\end{tabular}

Abbreviations are similar to Table 1.

Table 5. Economics of foliar application of macro and micro nutrients on guava orchard cv. Hisar Safeda.

\begin{tabular}{lcccc}
\hline Treatments & $\begin{array}{c}\text { Yield } \\
\text { (kg/ha) }\end{array}$ & $\begin{array}{c}\text { Gross income } \\
(\text { Rs/ha })\end{array}$ & $\begin{array}{c}\text { Total cost } \\
\text { (Rs/ha) }\end{array}$ & B: C ratio \\
\hline $\mathrm{T}_{1}$ (Rainy) & 12254.24 & 169108.51 & 138490.50 & 1.22 \\
$\mathrm{~T}_{1}$ (Winter) & 15234.40 & 228516.00 & 138490.50 & 1.65 \\
$\mathrm{~T}_{2}$ (Rainy) & 12585.06 & 176190.84 & 137072.70 & 1.29 \\
$\mathrm{~T}_{2}$ (Winter) & 15479.04 & 232185.60 & 137072.70 & 1.69 \\
$\mathrm{~T}_{3}$ (Rainy) & 13349.56 & 202913.31 & 135874.50 & 1.49 \\
$\mathrm{~T}_{3}$ (Winter) & 16752.28 & 268036.48 & 135874.50 & 1.97 \\
$\mathrm{~T}_{4}$ (Rainy) & 12932.56 & 193988.40 & 148715.10 & 1.30 \\
$\mathrm{~T}_{4}$ (Winter) & 15884.92 & 254158.72 & 148715.10 & 1.71 \\
$\mathrm{~T}_{5}$ (Rainy) & 13849.96 & 221599.36 & 146099.10 & 1.52 \\
$\mathrm{~T}_{5}$ (Winter) & 17744.74 & 299886.11 & 146099.10 & 2.05 \\
$\mathrm{~T}_{6}$ (Rainy) & 13669.26 & 215974.31 & 147516.90 & 1.46 \\
$\mathrm{~T}_{6}$ (Winter) & 17227.66 & 284256.39 & 147516.90 & 1.93 \\
$\mathrm{~T}_{7}$ (Rainy) & 14353.14 & 244003.38 & 157741.50 & 1.55 \\
$\mathrm{~T}_{7}$ (Winter) & 18270.16 & 337997.96 & 157741.50 & 2.14 \\
$\mathrm{~T}_{8}$ (Rainy) & 11965.12 & 151957.02 & 127148.10 & 1.20 \\
$\mathrm{~T}_{8}$ (Winter) & 14550.52 & 210982.54 & 127148.10 & 1.66 \\
\hline $\mathrm{Ab}^{2}$ & & & & \\
\hline
\end{tabular}

Abbreviations are similar to Table 1.

The maximum shoot $\mathrm{C}$ : $\mathrm{N}$ ratio was recorded in the guava trees treated with $\mathrm{T}_{7}$ foliar treatment which was found statistically at par with $\mathrm{T}_{5}, \mathrm{~T}_{3}, \mathrm{~T}_{4}$ and $\mathrm{T}_{6}$ treatments (Table 4) and minimum in the control trees. The highest carbohydrate content in shoots might be due to the fact that boron enhanced the accumulation of carbohydrate in flowering shoots. Boron is involved in carbohydrate transport within plant. Boron ion may be associated with cell membrane where it makes a complex with sugar molecules and facilitate its passage across the membranes. The increment in the carbohydrate content was greater than the nitrogen content, accordingly the C: $\mathrm{N}$ 
ratio considerably increased throughout the period. Similar findings have been reported in mango by Sen (1973). The shoot C: N ratio was not affected significantly by seasons and interaction effect of various foliar applications and seasons.

The maximum benefit: cost ratio was recorded in $\mathrm{T}_{7}$ foliar treatment which was followed by $\mathrm{T}_{5}$ in both seasons (Table 5). However, the control treatment resulted in minimum benefit: cost ratio during rainy and winter season. The increase in benefit: cost ratio might be attributed to the fact that improved yield and quality in $\mathrm{T}_{7}$ foliar application fetched good price in the market.

It may be concluded from the present investigation that combined foliar spray of macro and micro nutrients at vegetative, flowering and fruiting stage can increase the quality as well as yield of guava. The rainy season crop being slightly at the lower side in terms of quality and yield in comparison to winter season crop, it is preferable to take winter season crop for higher returns.

\section{References}

Bal JS 2006. Fruit growing. $2^{\text {nd }}$ edition. Kalyani Publishers. Rajinder Nagar, Ludhiana, Punjab.

Brahmachari VS, Yadav GS and Kumar N 1997. Effect of foliar feeding of calcium, zinc and boron on yield and quality attributes of litchi (Litchi chinensis Sonn). Orissa J. Hort. 25(1): 49.

Ganie MA, Akhter F, Bhat MA, Malik AR, Junaid JM, Shah MA and Bhat TA 2013. Boron- A critical nutrient element for plant growth and productivity with reference to temperate fruits. Curr. Sci. 76-85.

Higazi AH, Ahmed SA and El Hagah MH 1984. Effect of foliar fertilization with Irral and urea on yield, fruit set and physio-chemical composition of guava fruits (Psidium guajava L.). Minufiya J. Agric. Res. 8: 319-330.

Jackson ML 1973. Soil Chemical Analysis, Advanced Prentice Hall of India Pvt. Ltd., New Delhi, India.

Jat G and Kacha HL 2014. Response of guava to foliar application of urea and zinc on fruit set, yield and quality. J. A. S. 1(2): 86-91.

Kharwade SB, Surnar LB and Syed SJ 2018. Effect of foliar application of different chemicals on yield and economics of guava (Psidium guajava L.) var. Sardar. I. J. M. A. S. 6: 1755-1760.

Kumar J, Kumar R, Rai R and Mishra DS 2015. Response of 'Pant Prabhat'guava trees to foliar sprays of zinc, boron, calcium and potassium at different plant growth stages. The Bioscan 10(2): 495-498.

Panse VG and Sukhatme PV 1985. Statistical Methods for Agricultural Workers, $4^{\text {th }}$ edition, ICAR, New Delhi.

Saxena M and Gandhi CP 2017. Indian Horticulture Database, National Horticulture Board, Ministry of Agriculture, Government of India, Gurugram, Haryana.

Sen S 1973. Changes in nitrogen in mango leaves during early spring growth. Indian J. Agric. Res. 17(4): 293-299.

Sharma A, Wali VK, Bakshi P and Jasrotia A 2013. Effect of integrated nutrient management strategies on nutrient status, yield and quality of guava. Indian J. Hor. 70(3): 333-339.

Sharma RK, Kumar R and Thakur S 1991. Effect of foliar application feeding of potassium, calcium and zinc on yield and quality of guava. Indian J. Hortic. 48(4): 312-314.

Singh RS and Vashishtha BB 1997. Effect of foliar spray of nutrients on fruit drop, yield and quality of ber (Zizyphus mauritiana Lamk) cv. Seb. Haryana J. Hort. Sci. 26: 20-23.

Somogyi N 1952. Notes on sugar determination. J. Biol. Chem. 200: 145-154.

Verma ML and Chauhan JK 2013. Effect of integrated nutrient application on apple productivity and soil fertility in temperate zone of Himachal Pradesh. Int. J. Farm. Sci. 3(2): 19-27.

Zaman Q and Schumann AW 2006. Nutrient management zones for citrus based on variation in soil properties and tree performance. Precis. Agric. 7(1): 45-63. 